\title{
SLAMF6 is associated with the susceptibility and severity of rheumatoid arthritis in the Chinese population
}

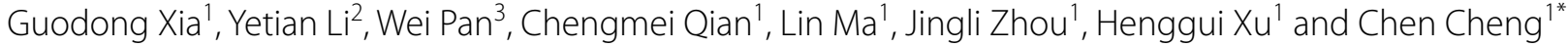

\begin{abstract}
Objectives: A recently published genome-wide association study identified six novel loci associated with rheumatoid arthritis (RA) in Korean population. We aimed to investigate whether these newly reported RA-risk loci are associated with RA in the Chinese population and to further characterize the functional role of the susceptible gene.

Methods: The susceptible variants of RA were genotyped in 600 RA patients and 800 healthy controls, including rs 148363003 of SLAMF6, rs 117605225 of CXCL13, rs360136 of SWAP70, rs 111597524 of NFKBIA, rs 194757 of ZFP36L1 and rs 1547233 of LINC00158. Synovial tissues were collected from the knee joint of 50 RA patients and 40 controls without osteoarthritis for the gene expression analysis. Inter-group comparisons were performed with the Chi-square test for genotyping data or with Student's t-test for gene expression analysis.
\end{abstract}

Result: For rs 148363003 of SLAMF6, RA patients were observed to have a significantly lower frequency of genotype CC ( $4.5 \%$ vs. $0.9 \%, p=0.004)$ as compared with the controls. The frequency of allele $C$ was remarkably higher in the patients than in the controls (11.5\% vs. 8.0\%, $p=0.002)$, with an odds ratio of $1.49(95 \% \mathrm{Cl}=1.16-1.92)$. There was no significant difference between the patients and the controls regarding genotype or allele frequency of the other 5 variants. The mRNA expression of SLAMF6 was 1.6 folds higher in the RA patients than in the controls. Moreover, SLAMF6 expression was 1.5 folds higher in patients with genotype CC than in the patients with genotype TT.

Conclusions: SLAMF6 was associated with both the susceptibility and severity of RA in the Chinese population. Moreover, rs 148363003 could be a functional variant regulating the tissue expression of SLAMF6 in RA patients. It is advisable to conduct further functional analysis for a comprehensive knowledge on the contribution of this variant to the development of RA.

Keywords: Rheumatoid arthritis, Susceptible, SLAMF6, Severity

\section{Introduction}

Rheumatoid arthritis (RA) is a complex autoimmune disorder characterized by destruction of cartilage and joint caused by inflammatory synovitis $[1,2]$. RA usually develops between 40 and 50 years of age. The prevalence of the disease was estimated to be $0.5-1 \%$

\footnotetext{
*Correspondence: chenctaizhou@126.com

${ }^{1}$ Department of Orthopaedic Surgery, The JiangYan TCM Hospital of Taizhou City, Jiang Yan Road No. 699, Taizhou City 225500, China Full list of author information is available at the end of the article
}

among the world population and was more frequently developed in women than in men [3-5]. Although the etiology of RA is yet to be uncovered, earlier studies demonstrated that both environmental and genetic risk factors might play a major role in the onset and progression of the disease [6-8]. Previous familial studies indicated the risk of RA was remarkably higher in subjects with a familial history of RA, which was likely to be attributed to both inherited and environmental factors $[9,10]$. The overall heritability of RA has been estimated to be about $50-65 \%$ by twin studies $[11,12]$. original author(s) and the source, provide a link to the Creative Commons licence, and indicate if changes were made. The images or other third party material in this article are included in the article's Creative Commons licence, unless indicated otherwise in a credit line to the material. If material is not included in the article's Creative Commons licence and your intended use is not permitted by statutory regulation or exceeds the permitted use, you will need to obtain permission directly from the copyright holder. To view a copy of this licence, visit http://creativecommons.org/licenses/by/4.0/. The Creative Commons Public Domain Dedication waiver (http://creativecommons.org/publicdomain/zero/1.0/) applies to the data made available in this article, unless otherwise stated in a credit line to the data. 
Apparently, a combination between genetic background and environmental triggers confers an increased risk for RA.

To date, numerous efforts have been undertaken to identify specific genes and pathways implicated in the development of RA. Genome-wide association studies (GWAS) have discovered more than $100 \mathrm{RA}$-associated genetic variants in multiple ancestries [13-17]. Julia et al. [18] analyzed 317,503 SNPs in 400 RA patients and 400 controls and identified KLF12 as a new susceptibility gene for RA in the Spanish population. Saxena et al. [19] tested $>7$ million SNPs in a total of 511 RA cases and 352 healthy controls and reported 2 novel associations specific to Arab populations at the $5 \mathrm{q} 13$ and $17 \mathrm{p} 13$ loci. According to the most recent studies, previously reported loci were able to explain only about $15 \%$ of the total risk in susceptibility to RA [15]. Considering substantial missing fraction of heritability, continuous effort in identifying additional RA variants is thus necessary to better understand the disease etiology.

In a recently published meta-analysis of GWAS for 4068 RA cases and 36,487 healthy controls, Kwon et al. [15] identified six novel RA-risk loci that reached the genome-wide significance in Korean population. It is now well established that for GWAS findings in complex disease genetics, one of the pivotal tasks is to further replicate genetic changes in different populations and link these susceptible variants to potential gene functions. In this study, we aimed to investigate whether the newly reported RA-risk loci were associated with RA in the Chinese population and to further characterize the functional role of the susceptible gene.

\section{Methods}

\section{Subjects}

Under the approval of the Ethics Committee of our institutions, a cohort of 600 RA patients who visited our center for treatment between June 2014 and October 2020 were enrolled in this study. All the patients were from Chinese Han population, who were diagnosed as RA according to the 2010 American College of Rheumatology criteria for RA classification [20]. The 28-Joint Count Disease Activity Score (DAS28) was used to assess the disease activity for each patient [21,22]. Patients with DAS28 $>3.2$ were classified as active RA, and patients with DAS28 $\leq 3.2$ were classified as inactive RA. Eight hundred age-matched healthy subjects were recruited as normal controls. The baseline characteristics of RA patients were collected from the medical records, including age, gender, body mass index (BMI), the serum level of rheumatoid factor (RF), erythrocyte sedimentation rate (ESR) and C-reactive protein (CRP).

\section{Genotyping of target SNPs}

With the informed consent obtained from the subjects, blood samples were then collected for genomic DNA extraction using the commercial kit (QIAGEN, Tokyo, Japan), which were then stored at $-20{ }^{\circ} \mathrm{C}$. Approximately $10 \mathrm{ng}$ of the DNA sample was used for genotyping of the following 6 SNPs with TaqMan SNP Genotyping Assay, including rs 148363003 of SLAMF6, rs117605225 of CXCL13, rs360136 of SWAP70, rs111597524 of NFK$B I A$, rs194757 of ZFP36L1 and rs1547233 of LINC00158. Amplification was performed in $20 \mu \mathrm{l}$ reaction volumes, containing $2 \mu \mathrm{l}$ of TaqMan genotyping assay mix, $6 \mu \mathrm{l}$ of genomic DNA, $2 \mu \mathrm{l}$ of distilled deionized water and $10 \mu \mathrm{l}$ of the TaqMan genotyping master mix. The interpretation of genotyping assay results was read on ABI 7900HT sequence detection system (Applied Biosystem, Foster City, CA). Twenty percent of the tests were randomly repeated to validate the reproducibility of the genotyping results.

\section{Gene expression analysis of SLAMF6}

During total knee replacement surgery, samples of synovial tissues were collected from the knee joint of $50 \mathrm{RA}$ patients. Forty patients undergoing surgery for cruciate ligament rupture or meniscus tear were recruited as the control group. The mean age of the RA patients was $44.6 \pm 11.9$ years and their mean disease duration was 52.1 months (range 19-129 months). The mean ages of the control group were $42.2 \pm 9.5$ years. The total RNA was extracted from synovial tissues using Trizol reagent (QIAGEN, Tokyo, Japan) according to the standard protocol, which was then reversely transcribed by the PrimeScriptRT Master Mix kit (TaKaRa, Tokyo, Japan). The mRNA expression of SLAMF6 was quantified by quantitative real-time PCR (qPCR) with glyceraldehyde-3-phosphate dehydrogenase (GAPDH) used as internal controls. The gene-specific primers were as follows, forward $5^{\prime}$ GAGTCCGCAAGGAACCTAGAG- $3^{\prime}$, reverse $5^{\prime}$-TCC CTGTTTGAATGAGTGACTGA- $3^{\prime}$ for POC5, and forward 5'-GAGTCAACGGATTTGGTCGT-3', reverse $5^{\prime}$-TTGATTTTGGAGGGATCTCG-3' for GAPDH that functions as endogenous control. All amplification reactions were carried out in triplicate.

\section{Statistical analysis}

For continuous descriptive data, the results were displayed as the mean \pm standard deviation (SD). The Hardy-Weinberg equilibrium (HWE) method was used to examine the genotype frequency of the normal controls. The Chi-square analysis was used to compare the frequency of genotype and risk allele between the RA cases and controls, with the odds ratio (OR) and 95\% 
confidential intervals (CIs) calculated for each SNP. Intergroup comparison of the expression of SLAMF6 was assessed by the Student's t-test. Correlations between $S L A M F 6$ expression and serum indexes were analyzed by Spearman's correlation analysis. The SPSS software (version 23.0, Chicago, USA) was used for statistical analysis. A $P$ value of less than 0.05 was considered statistically significant.

\section{Results}

\section{Demographic data of the subjects}

The baseline clinical characteristics of the subjects are summarized in Table 1. For association analysis, there was no significant difference between the patients and the controls regarding the mean age $(43.4 \pm 12.9$ vs. $42.6 \pm 13.4, p=0.26)$, BMI $(24.1 \pm 5.6$ vs. $24.4 \pm 4.9$, $p=0.29)$ or gender $(p=0.22)$. The mean ESR level was $21.1 \pm 11.9 \mathrm{~mm} / \mathrm{h}$ in RA patients. The mean value of $\mathrm{RF}$ and CRP was $84.8 \pm 7.8$ (IU) $/ \mathrm{ml}$ and $44.3 \pm 19.7 \mathrm{mg} / \mathrm{L}$, respectively.

Table 1 Baseline characteristics of the subjects

\begin{tabular}{llll}
\hline & Patients $(\boldsymbol{n}=\mathbf{6 0 0})$ & Controls $(\boldsymbol{n}=\mathbf{8 0 0})$ & $\boldsymbol{P}$ \\
\hline Age (years) & $43.4 \pm 12.9$ & $42.6 \pm 13.4$ & 0.26 \\
Gender (male/female) & $192: 408$ & $281: 519$ & 0.22 \\
BMl $\left(\mathrm{kg} / \mathrm{m}^{2}\right)$ & $24.1 \pm 5.6$ & $24.4 \pm 4.9$ & 0.29 \\
DAS28 & $3.5 \pm 1.6$ & $\mathrm{~N} / \mathrm{A}$ & $\mathrm{N} / \mathrm{A}$ \\
ESR $(\mathrm{mm} / \mathrm{h})$ & $21.1 \pm 11.9$ & $\mathrm{~N} / \mathrm{A}$ & $\mathrm{N} / \mathrm{A}$ \\
RF $(\mathrm{IU} / \mathrm{ml})$ & $84.8 \pm 7.8$ & $\mathrm{~N} / \mathrm{A}$ & $\mathrm{N} / \mathrm{A}$ \\
CRP $(\mathrm{mg} / \mathrm{L})$ & $44.3 \pm 19.7$ & $\mathrm{~N} / \mathrm{A}$ & $\mathrm{N} / \mathrm{A}$ \\
& & &
\end{tabular}

\section{Replication of RA-associated variants}

HWE test revealed no remarkable difference regarding the genotype frequency among the controls. As shown in Table 2, for rs 148363003 of SLAMF6, RA patients were observed to have a significantly higher frequency of genotype CC ( $4.5 \%$ vs. $0.9 \%, p=0.004)$ as compared with the controls. The frequency of allele $\mathrm{C}$ was remarkably higher in the patients than in the controls $(11.5 \%$ vs. $8.0 \%$, $p=0.002)$, with an odds ratio of $1.49(95 \% \mathrm{CI}=1.16$ 1.92). There was no significant difference between the patients the controls regarding genotype or allele frequency of the other 5 variants.

\section{Tissue expression of the SLAMF6}

A total of 50 RA patients and 40 non-RA controls were included in expression analysis. The two groups were matched in terms of age $(44.6 \pm 11.9$ years vs. $42.2 \pm 9.5$ years, $p=0.29)$ and BMI $(24.8 \pm 3.6$ vs. $24.1 \pm 3.9, p=0.37)$. As illustrated in Fig. 1A, the mRNA expression of SLAMF6 was 1.6 folds higher in the RA patients than in the controls $(0.000625 \pm 0.0000232$ vs. $0.000390 \pm 0.000132, p<0.001)$. For RA patients, there were 40 cases with genotype TT of rs148363003 and 10 cases with genotype CC. As shown in Fig. 1B, the mRNA expression of SLAMF6 was 1.5 folds higher in patients with genotype $\mathrm{CC}$ than in the patients with genotype TT $(0.000853 \pm 0.000148$ vs. $0.000568 \pm 0.000214, p<0.001)$.

\section{Relationship between SLAMF6 and clinical phenotypes of RA}

Of the 50 RA patients included in tissues analysis, 27 patients had DSA28 of more than 3.2, who were thus assigned to active RA group. Inter-group comparison

Table 2 Comparison of the genotype and allele frequency between the patients and controls

\begin{tabular}{|c|c|c|c|c|c|c|c|c|c|}
\hline & & \multicolumn{3}{|l|}{ Genotype } & \multirow[t]{2}{*}{$P$} & \multicolumn{2}{|l|}{ Allele } & \multirow[t]{2}{*}{$P$} & \multirow[t]{2}{*}{ Odds ratio $\left(95 \% \mathrm{Cl}^{\mathrm{a}}\right)$} \\
\hline & & $X X$ & $X x$ & $x x$ & & $X$ & $\mathbf{x}$ & & \\
\hline \multirow[t]{2}{*}{ rs148363003 } & Patients $(n=600)$ & $489(81.5 \%)$ & $84(14.0 \%)$ & $27(4.5 \%)$ & 0.004 & $1062(88.5 \%)$ & $138(11.5 \%)$ & 0.002 & $1.49(1.16-1.92)$ \\
\hline & Controls $(n=800)$ & 679 (84.9\%) & $114(14.2 \%)$ & $7(0.9 \%)$ & & $1472(92.0 \%)$ & $128(8.0 \%)$ & & \\
\hline \multirow[t]{2}{*}{ rs117605225 } & Patients $(n=600)$ & $570(95.0 \%)$ & $26(4.3 \%)$ & $4(0.7 \%)$ & 0.54 & $1166(97.2 \%)$ & $34(2.8 \%)$ & 0.52 & $0.87(0.56-1.34)$ \\
\hline & Controls $(n=800)$ & $750(93.8 \%)$ & $48(6.0 \%)$ & $2(0.2 \%)$ & & $1548(96.7 \%)$ & $52(3.3 \%)$ & & \\
\hline \multirow[t]{2}{*}{ rs360136 } & Patients $(n=600)$ & $180(30.0 \%)$ & $291(48.5 \%)$ & $129(21.5 \%)$ & 0.92 & $652(54.3 \%)$ & $548(46.7 \%)$ & 0.95 & $1.01(0.86-1.16)$ \\
\hline & Controls $(n=800)$ & $234(29.2 \%)$ & $403(50.4 \%)$ & $163(20.4 \%)$ & & $871(54.4 \%)$ & $729(46.6 \%)$ & & \\
\hline \multirow[t]{2}{*}{ rs111597524 } & Patients $(n=600)$ & $301(50.2 \%)$ & $280(46.6 \%)$ & $19(3.2 \%)$ & 0.71 & $882(73.4 \%)$ & $318(26.6 \%)$ & 0.74 & $0.97(0.82-1.15)$ \\
\hline & Controls $(n=800)$ & $388(48.5 \%)$ & 391 (48.9\%) & $21(2.6 \%)$ & & 1167 (72.9\%) & 433 (27.1\%) & & \\
\hline \multirow[t]{2}{*}{ rs194757 } & Patients $(n=600)$ & $284(47.4 \%)$ & $256(42.6 \%)$ & $60(10.0 \%)$ & 0.18 & 824 (68.7\%) & $376(31.3 \%)$ & 0.22 & $0.91(0.77-1.06)$ \\
\hline & Controls $(n=800)$ & 351 (43.9\%) & $362(45.3 \%)$ & 87 (10.9\%) & & 1064 (66.5\%) & $536(33.5 \%)$ & & \\
\hline \multirow[t]{2}{*}{ rs1547233 } & Patients $(n=600)$ & $332(55.3 \%)$ & $244(40.8 \%)$ & $24(4.0 \%)$ & 0.20 & 908 (75.6\%) & $292(24.4 \%)$ & 0.37 & $0.92(0.78-1.09)$ \\
\hline & Controls $(n=800)$ & 423 (52.9\%) & $332(41.5 \%)$ & 45 (5.6\%) & & 1187 (73.7\%) & $413(26.4 \%)$ & & \\
\hline
\end{tabular}



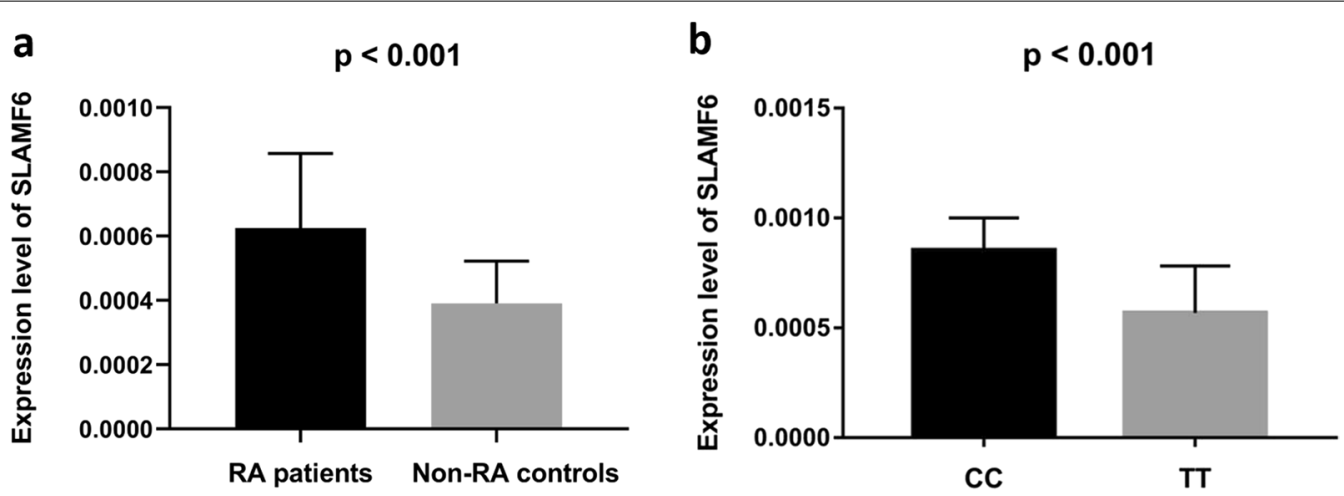

Fig. 1 Tissue expression of SLAMF6 in RA patients. a RA patients were found to have remarkably increased expression of SLAMF6 gene as compared with the controls. b The mRNA expression of SLAMF6 was 1.5 folds higher in patients with genotype CC than in the patients with genotype $\Pi T$

showed that patients in active RA group $(n=27)$ had significantly higher SLAMF6 expression than those in inactive RA group $(n=23)(0.000708 \pm 0.000210$ vs. $0.000527 \pm 0.000222, p=0.005$ ) (Fig. 2a). As shown in Fig. 2b, the mRNA expression level of SLAMF6 was remarkably correlated with serum $\mathrm{RF}(r=0.30$, $p=0.03)$. As for ESR $(r=0.08, p=0.60)$ and CRP $(r=-0.15, p=0.29)$, no significant correlation with SLAMF6 expression was found.

\section{Discussion}

As recent meta-analysis of GWAS data in Korean cohorts identified 6 novel loci of RA [15], we replicated these variants in the Chinese RA patients and confirmed that rs148363003 of SLAMF6 was associated with RA in the Chinese population. For rs148363003, allele $\mathrm{T}$ was a wild-type allele, and allele $\mathrm{C}$ was a mutant allele. Genotype CC was indicative of remarkably higher risk of RA. We observed that allele $C$ of rs 148363003 can remarkably add to the risk of RA by 1.49 folds, which was

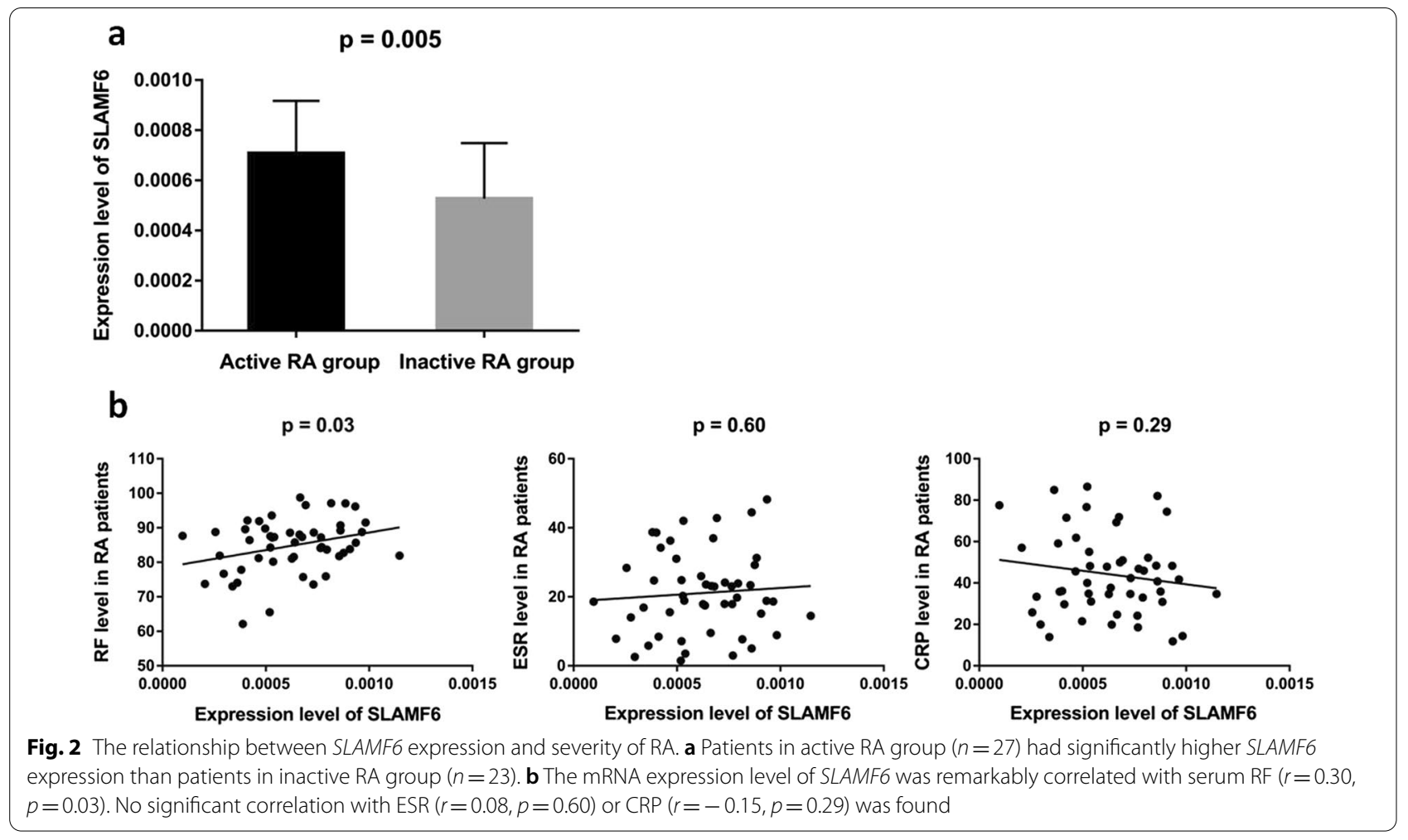


consistent with an increased RA risk of 1.62 folds in the Korea population as reported by Kwon et al. [15]. The rs148363003 is located at $11 \mathrm{~kb}$ downstream of SLAMF6. Through expression quantitative trait locus mapping based on public database, Kwon et al. [15] reported that rs 148363003 had chromatin interactions with 13 coding genes on chromosome 1 . To further clarify the biological basis underlying the association between rs 148363003 and the risk of RA, we preliminarily investigated the relationship between rs148363003 and tissue expression of $S L A M F 6$. For the first time, we analyzed the expression of SLAMF6 gene in the synovial tissues of RA patients as well as in the controls. Remarkably higher tissue expression of SLAMF6 was observed in RA patients than in the controls. Moreover, patients with genotype $\mathrm{CC}$ of rs148363003 were found to have remarkably increased expression of SLAMF6 than those with genotype TT. Since the frequency of genotype $\mathrm{CC}$ was remarkably higher in patients than in normal controls, it was plausible that the mutant allele $\mathrm{C}$ added to the risk of RA via regulation of SLAMF6. Interestingly, as shown in HaploReg database [23], rs148363003 is predicted to alter transcription factor-binding sites of SLAMF6. A finemapping of the genomic region around rs148363003 is warranted to further elucidate its regulatory role in the tissue expression of SLAMF6.

As reported in previous studies, the susceptible genes of RA could be associated with the severity of the disease [24-26]. Elkhawaga et al. [24] reported that rs28362491 of NFKB1 contributed to both susceptibility and severity of RA. Zhao et al. [25] reported that rs1801278 of IRS-1 was associated with increased risk and disease activity of RA. In this study, the relationship between SLAMF6 and RA activity was also analyzed. Patients with high RA activity were found to have significantly higher SLAMF6 expression than patients with low RA activity. Moreover, there was significant correlation between SLAMF6 expression and serum RF. Collectively, SLAMF6 may act as a modifier gene which is prognostic of the progression of RA.

To date, the exact function of SLAMF6 in RA remains obscure. The product of SLAMF6 is a member of superfamily immunoglobulin (Ig) domain-containing molecules that play a role in interactions between naive lymphocytes. Previous functional studies indicated that the SLAMF6 could be involved in a series of inflammatory diseases [27-29]. Wang et al. [27] reported that SLAMF6 might function as an inhibitory receptor that regulates autoimmune responses. Savola et al. [29] reported accumulation of mutations in SLAMF6 in expanded $\mathrm{T}$ cells may have pathogenic significance for RA. Other members of SLAMF have been reported to contribute to the accumulation of antibody producing cells in patients with systemic lupus erythematosus, which therefore were considered as potential therapeutic targets for autoimmune diseases [30]. In the current study, we preliminarily observed that the tissues expression of SLAMF6 was associated with RA activity. Further investigation into the relationship between serum soluble SLAMF6 concentration and clinical characteristics of RA patients is warranted to better decipher the potential application of SLAMF6 as a clinical biomarker for RA.

In the current study, no association between the 5 SNPs and RA in the Chinese population was found in the current study. However, we still cannot entirely exclude the association of these 5 genes with RA. Several limitations of this study should be addressed here. First, due to the inherent defect of retrospective research, the lack of replication was probably attributed to the relatively small sample size of current study. Larger sample size may help yield more convincing outcome. Second, we used patients with cruciate ligament rupture or meniscus tear as control group for gene expression of SLAMF6 in synovial tissue. It was difficult to collect synovial tissue from healthy population. The third limitation of the present study lies in that no in vivo experiment was performed to clarify the regulatory role of rs148363003 in SLAMF6 expression. Further functional experiments are therefore necessary to clarify the underlying regulatory mechanism.

\section{Conclusions}

SLAMF6 was associated with both the susceptibility and severity of RA in the Chinese population. Moreover, rs148363003 could be a functional variant regulating the tissue expression of SLAMF6 in RA patients. It is advisable to conduct further functional analysis for a comprehensive knowledge on the contribution of this variant to the development of RA.

\section{Abbreviations \\ RA: Rheumatoid arthritis; GWAS: Genome-wide association studies; DAS28: 28-Joint Count Disease Activity Score; BMI: Body Mass Index; RF: Rheumatoid factor; ESR: Erythrocyte sedimentation rate; CRP: C-reactive protein; HWE: Hardy-Weinberg equilibrium; OR: Odds ratio; Cls: Confidential intervals.}

\section{Acknowledgements \\ We sincerely thank all the patients recruited in this study.}

\section{Authors' contributions}

XG and PW collected the data and drafted the manuscript. LY, ZJ, QC and ML performed the laboratory experiments. $\mathrm{CC}$ and $\mathrm{XH}$ reviewed and revised the manuscript. All authors read and approved the final manuscript.

\section{Funding}

No funding was used in this research.

Availability of data and materials

All data used in this study are available at the request of editors, reviewers and the research community. 


\section{Declarations}

\section{Ethical approval and consent to participate}

Written consent was obtained from each subject. The histological study of surgical samples was approved by the Institutional Ethics Committee (IRB of The JiangYan TCM Hospital, 2020/11/30). All experimental protocols and methods were carried out in accordance with relevant guidelines and regulations, and complied with the Helsinki Declaration.

\section{Consent for publication}

All the authors agreed to publish this paper.

\section{Competing interests}

The authors declare that they have no competing interests.

\section{Author details \\ 'Department of Orthopaedic Surgery, The Jiang Yan TCM Hospital of Taizhou City, JiangYan Road No. 699, Taizhou City 225500, China. ${ }^{2}$ Department of Orthopaedic Surgery, The First Affiliated Hospital of Anhui Medical Uni- versity, Hefei City, China. ${ }^{3}$ Department of Orthopaedic Surgery, The Huai'an Second People's Hospital, Huai'an City, China.}

Received: 18 September 2021 Accepted: 30 December 2021

Published online: 11 January 2022

\section{References}

1. Lefevre S, Meier FM, Neumann E, Muller-Ladner U. Role of synovial fibroblasts in rheumatoid arthritis. Curr Pharm Des. 2015;21:130-41.

2. Verma MK, Sobha K. Understanding the major risk factors in the beginning and the progression of rheumatoid arthritis: current scenario and future prospects. Inflamm Res. 2015;64:647-59.

3. Andrianakos A, Trontzas P, Christoyannis F, Kaskani E, Nikolia Z, Tavaniotou E, Georgountzos A, Krachtis P. Prevalence and management of rheumatoid arthritis in the general population of Greece-the ESORDIG study. Rheumatology (Oxford). 2006;45:1549-54.

4. Kuo CF, Luo SF, See LC, Chou IJ, Chang HC, Yu KH. Rheumatoid arthritis prevalence, incidence, and mortality rates: a nationwide population study in Taiwan. Rheumatol Int. 2013;33:355-60.

5. Slimani S, Ladjouze-Rezig A. Prevalence of rheumatoid arthritis in an urban population of Algeria: a prospective study. Rheumatology (Oxford) 2014:53:571-3.

6. Albani S, Carson DA, Roudier J. Genetic and environmental factors in the immune pathogenesis of rheumatoid arthritis. Rheum Dis Clin N Am. 1992;18:729-40.

7. Lundberg K, Bengtsson C, Kharlamova N, Reed E, Jiang X, Kallberg H, Pollak-Dorocic I, Israelsson L, Kessel C, Padyukov L, Holmdahl R, Alfredsson L, Klareskog L. Genetic and environmental determinants for disease risk in subsets of rheumatoid arthritis defined by the anticitrullinated protein/ peptide antibody fine specificity profile. Ann Rheum Dis. 2013;72:652-8.

8. Traylor M, Curtis C, Patel H, Breen G, Hyuck Lee S, Xu X, Newhouse S, Dobson R, Steer S, Cope AP, Markus HS, Lewis CM, Scott IC. Genetic and environmental risk factors for rheumatoid arthritis in a UK African ancestry population: the GENRA case-control study. Rheumatology (Oxford). 2017:56:1282-92

9. Hemminki K, Li X, Sundquist J, Sundquist K. Familial associations of rheumatoid arthritis with autoimmune diseases and related conditions. Arthritis Rheum. 2009:60:661-8.

10. Frisell T, Holmqvist M, Kallberg H, Klareskog L, Alfredsson L, Askling J. Familial risks and heritability of rheumatoid arthritis: role of rheumatoid factor/anti-citrullinated protein antibody status, number and type of affected relatives, sex, and age. Arthritis Rheum. 2013;65:2773-82.

11. Prahalad S, Ryan MH, Shear ES, Thompson SD, Glass DN, Giannini EH Twins concordant for juvenile rheumatoid arthritis. Arthritis Rheum. 2000:43:2611-2

12. Webster AP, Plant D, Ecker S, Zufferey F, Bell JT, Feber A, Paul DS, Beck S, Barton A, Williams FMK, Worthington J. Increased DNA methylation variability in rheumatoid arthritis-discordant monozygotic twins. Genome Med. 2018:10:64.
13. Julia A, Fernandez-Nebro A, Blanco F, Ortiz A, Canete JD, Maymo J, AlperiLopez M, Fernandez-Gutierrez B, Olive A, Corominas H, Erra A, AcostaColman I, Alonso A, Lopez-Lasanta M, Tortosa R, Tornero J, Marsal S. A genome-wide association study identifies a new locus associated with the response to anti-TNF therapy in rheumatoid arthritis. Pharmacogenomics J. 2016;16:147-50.

14. Julia A, Gonzalez I, Fernandez-Nebro A, Blanco F, Rodriguez L, Gonzalez A, Canete JD, Maymo J, Alperi-Lopez M, Olive A, Corominas H, MartinezTaboada V, Erra A, Sanchez-Fernandez S, Alonso A, Lopez-Lasanta M, Tortosa R, Codo L, Gelpi JL, Garcia-Montero AC, Bertranpetit J, Absher D, Bridges SL Jr, Myers RM, Tornero J, Marsal S. A genome-wide association study identifies SLC8A3 as a susceptibility locus for ACPA-positive rheumatoid arthritis. Rheumatology (Oxford). 2016;55:1106-11.

15. Kwon YC, Lim J, Bang SY, Ha E, Hwang MY, Yoon K, Choe JY, Yoo DH, Lee SS, Lee J, Chung WT, Kim TH, Sung YK, Shim SC, Choi CB, Jun JB, Kang YM, Shin JM, Lee YK, Cho SK, Kim BJ, Lee HS, Kim K, Bae SC. Genome-wide association study in a Korean population identifies six novel susceptibility loci for rheumatoid arthritis. Ann Rheum Dis. 2020:79:1438-45.

16. Freudenberg J, Lee HS, Han BG, Shin HD, Kang YM, Sung YK, Shim SC, Choi CB, Lee AT, Gregersen PK, Bae SC. Genome-wide association study of rheumatoid arthritis in Koreans: population-specific loci as well as overlap with European susceptibility loci. Arthritis Rheum. 2011;63:884-93.

17. Padyukov L, Seielstad M, Ong RT, Ding B, Ronnelid J, Seddighzadeh M, Alfredsson L, Klareskog L. A genome-wide association study suggests contrasting associations in ACPA-positive versus ACPA-negative rheumatoid arthritis. Ann Rheum Dis. 2011;70:259-65.

18. Julia A, Ballina J, Canete JD, Balsa A, Tornero-Molina J, Naranjo A, AlperiLopez M, Erra A, Pascual-Salcedo D, Barcelo P, Camps J, Marsal S. Genomewide association study of rheumatoid arthritis in the Spanish population: KLF12 as a risk locus for rheumatoid arthritis susceptibility. Arthritis Rheum. 2008:58:2275-86

19. Saxena R, Plenge RM, Bjonnes AC, Dashti HS, Okada Y, Gad El Haq W, Hammoudeh M, Al Emadi S, Masri BK, Halabi H, Badsha H, Uthman IW, Margolin L, Gupta N, Mahfoud ZR, Kapiri M, Dargham SR, Aranki G, Kazkaz $L A$, Arayssi T. A multinational arab genome-wide association study identifies new genetic associations for rheumatoid arthritis. Arthritis Rheumatol. 2017;69:976-85.

20. Fautrel B, Combe B, Rincheval N, Dougados M, Committee ES. Level of agreement of the 1987 ACR and 2010 ACR/EULAR rheumatoid arthritis classification criteria: an analysis based on ESPOIR cohort data. Ann Rheum Dis. 2012;71:386-9.

21. Leong KP, Tan JWL, Gao X, Koh ET, Group TRAS. Conversion among the 28-joint count activity indices for rheumatoid arthritis. Eur J Rheumatol. 2020;7:105-11.

22. Greenmyer JR, Stacy JM, Sahmoun AE, Beal JR, Diri E. DAS28-CRP Cutoffs for high disease activity and remission are lower than DAS28-ESR in rheumatoid arthritis. ACR Open Rheumatol. 2020;2:507-11.

23. Ward LD, Kellis M. HaploReg: a resource for exploring chromatin states, conservation, and regulatory motif alterations within sets of genetically linked variants. Nucleic Acids Res. 2012;40:D930-934.

24. Elkhawaga SY, Gomaa MH, Elsayed MM, Ebeed AA. NFKB1 promoter -94 insertion/deletion ATTG polymorphism (rs28362491) is associated with severity and disease progression of rheumatoid arthritis through interleukin-6 levels modulation in Egyptian patients. Clin Rheumatol. 2021:40:2927-37.

25. Zhao H, Liu S, Long M, Peng L, Deng H, You Y. Arg972 insulin receptor substrate-1 polymorphism and risk and severity of rheumatoid arthritis. Int J Rheum Dis. 2016:19:141-5.

26. Kastbom A, Ahmadi A, Soderkvist P, Skogh T. The $158 \mathrm{~V}$ polymorphism of Fc gamma receptor type IIIA in early rheumatoid arthritis: increased susceptibility and severity in male patients (the Swedish TIRA project). Rheumatology (Oxford). 2005:44:1294-8.

27. Wang N, Keszei M, Halibozek P, Yigit B, Engel P, Terhorst C. Slamf6 negatively regulates autoimmunity. Clin Immunol. 2016:173:19-26.

28. Chatterjee M, Hedrich CM, Rauen T, loannidis C, Terhorst C, Tsokos GC. CD3-T cell receptor co-stimulation through SLAMF3 and SLAMF6 receptors enhances RORgammat recruitment to the IL17A promoter in human T lymphocytes. J Biol Chem. 2012;287:38168-77.

29. Savola P, Kelkka T, Rajala HL, Kuuliala A, Kuuliala K, Eldfors S, Ellonen P, Lagstrom S, Lepisto M, Hannunen T, Andersson El, Khajuria RK, Jaatinen T, Koivuniemi R, Repo H, Saarela J, Porkka K, Leirisalo-Repo M, Mustjoki 
S. Somatic mutations in clonally expanded cytotoxic T lymphocytes in patients with newly diagnosed rheumatoid arthritis. Nat Commun. 2017;8:15869.

30. Humbel M, Bellanger F, Fluder N, Horisberger A, Suffiotti M, Fenwick C Ribi C, Comte D. Restoration of NK cell cytotoxic function with elotuzumab and daratumumab promotes elimination of circulating plasma cells in patients with SLE. Front Immunol. 2021;12:760.

\section{Publisher's Note}

Springer Nature remains neutral with regard to jurisdictional claims in published maps and institutional affiliations.

- fast, convenient online submission

- thorough peer review by experienced researchers in your field

- rapid publication on acceptance

- support for research data, including large and complex data types

- gold Open Access which fosters wider collaboration and increased citations

- maximum visibility for your research: over 100M website views per year

At BMC, research is always in progress.

Learn more biomedcentral.com/submissions 